J. Clin. Chem. Clin. Biochem.

Vol. 21, 1983, pp. 659-663

\title{
Release of Enzymes from Rat Jejunal Mucosa during in vitro Incubation
}

\author{
By Bärbel Bossmann and R.J. Haschen \\ Institut für Klinische Biochemie, Martin-Luther-Universität Halle-Wittenberg, Halle, GDR
}

(Received March 1/June 10, 1983)

Summary: Results obtained with the in vitro Wilson-Wiseman method ((1954), J. Physiol. 123, 116-125) and with an in vivo perfusion model are compared. The in vitro method suffers from insufficient oxygenation. Five plasma membrane enzymes, five cytosol and two lysosomal enzymes were estimated. The medium consisted of Ringer solution without and with $10 \mathrm{mmol} / \mathrm{l}$ taurocholate. The greatest difference between both models is shown by the lysosomal enzymes, which are amply released in vitro but not in vivo. The in vitro to in vivo ratios of the release rates of cytosol enzymes vary from about 10 to less than one, suggesting deterioration by lysosomal cathepsins in certain cases. The removal of plasma membrane enzymes, particularly those that are characterized by superficial localization, is inhibited by hypoxia. This implies that the normal release of these enzymes, at least in part, is energy-dependent.

\section{Freisetzung von Enzymen aus der Jejunumschleimhaut der Ratte bei Inkubation in vitro}

Zusammenfassung: Es werden Ergebnisse verglichen, die mit der in vitro Wilson-Wiseman-Methode ((1954), J. Physiol. 123, 116-125) und mit einem in vivo-Perfusionsmodell erhalten wurden. Die in vitro-Methode leidet unter ungenügender Oxygenierung. 5 Plasmamembran-, 5 Cytosol- und 2 lysosomale Enzyme wurden bestimmt. Das Medium bestand aus Ringer-Lösung ohne und mit $10 \mathrm{mmol} / 1$ Taurocholat. Den größten Unterschied zwischen beiden Modellen zeigen die lysosomalen Enzyme, die in vitro, nicht aber in vivo reichlich freigesetżt werden. Das Verhältnis der Freisetzungsraten von Cytosolenzymen in vitro und in vivo schwankt von etwa 10 bis weniger als 1 . In gewissen Fällen scheint ein Abbau durch lysosomale Kathepsine eine Rolle zu spielen. Die Ablösung von Plasmamembranenzymen, besonders der oberflächlich lokalisierten, ist bei Hypoxie gehemmt. Demnach wäre die normale Freisetzung dieser Enzyme wenigstens teilweise energieabhängig.

\section{Introductiōn}

In a previous paper (1) the release of enzymes from intestinal mucosa in an in vivo experimental model was described. Segmental perfusion of proximal jejunum of the rat was applied to study the liberation of enzymes from the mucosa cells under the influence of Ringer solution and bile salts. Besides plasma membrane enzymes cytosol enzymes were released in considerable quantities. In contrast, lysosomal and mitochondrial enzymes did not enter the perfusion medium, a finding that excludes a serious injury to the mucusa cells.
Prior to these experiments an in vitro investigation was conducted using the well-known Wilson-Wiseman method. The results were strikingly different. The method has long been used for the study of the assimilation of food stuffs. Recently, however, it was convincingly demonstrated by $\operatorname{Ugolev}(2,3)$ that in this model oxygenation is insufficient. Therefore, our results obtained with this method should be useful to demonstrate the effect of hypoxia on enzyme release from intestinal mucosa. In this communication the results of the in vitro method are presented in comparison with those of the in vivo model. 


\section{Material and Methods}

\section{Experimental models}

Female white Wistar rats of an average weight of $200 \mathrm{~g}$ were used. They had been on a standard diet but were fasted overnight prior to the experiment. The method of segmental perfusion in vivo has been described previously (1). The Wilson-Wiseman method (4) was applied as described by Suda \& Ueda (5). $30 \mathrm{~cm}$ of the proximal jejunum were removed and carefully everted. One end was ligated, the interior filled with $2-3 \mathrm{ml}$ of Ringer solution and the other end attached to a narrow glass tube which was then lowered into a large tube filled with $55 \mathrm{ml}$ of bath fluid at $37^{\circ} \mathrm{C}$. Carbogen gas (oxygen: carbon dioxide 95:5) was slowly circulated through two additional openings of the large tube. The bath fluid consisted of Ringer solution for warm-blooded animals $(9.50 \mathrm{~g} \mathrm{NaCl}, 0.10 \mathrm{~g}$ $\mathrm{KCl}, 0.20 \mathrm{~g} \mathrm{CaCl}_{2}, 0.15 \mathrm{~g} \mathrm{NaHCO}_{3}$, and $1.00 \mathrm{~g}$ glucose per liter) without and with $10 \mathrm{mmol} / \mathrm{l}$ sodium taurocholate. This bile salt at this concentration was clearly effective in the in vivo experiments in releasing brush border and cytosol enzymes. At intervals during incubation $2 \mathrm{ml}$ samples of the bath fluid were removed, and replaced by Ringer solution. The dilution was corrected by calculation.

Enzyme and protein determinations

Five plasma membrane, five cytosol and two lysosomal enzymes (see tab. 1) and protein were determined as described in the previous paper (1). Inhibition of enzymes by $10 \mathrm{mmol} / \mathrm{l}$ taurocholate was corrected by caliculation; activation was not corrected because it is negligible (alkaline phosphatase, $\alpha$-1,4-glucosidase) or incalculable (enteropeptidase) (1). For comparison, the released quantities of protein and enzymes were related to $20 \mathrm{~cm}$ of jejunal segment.

\section{Results}

The cumulative amounts of protein and enzymes released after different time intervals are given in table 1. For better comparison, some typical observations are represented in figure 1 . In the in vitro investigations there are significant quantities of protein and enzymes in the medium at the beginning of the experiments. They are due to the unavoidable anoxic and mechanical injury of the intestinal mucosa during the preparation of the everted sacs. These zero time values might be subtracted from the values obtained after incubation. In our opinion it is more useful to consider the slopes of the curves which give an impression of the rates of enzyme release under the different experimental conditions. In vivo, after an initial lag phase a nearly linear increase can be seen. In vitro, however, the release rates tend to decrease during the experiment.

The plasma membrane enzymes, with the exception of alkaline phosphatase and alanine aminopeptidase, tend to smaller release rates in vitro than in vivo. This is true especially of enteropeptidase, but the phenomenon is also seen, though to a lesser degree,

Tab. 1. Cumulative quantities of protein and enzymes released after $0,30,60$ and 120 min of perfusion (in vivo) or incubation (in vitro). The intermediate values estimated in the in vivo experiments were omitted (see fig. 1). Control, Ringer solution; TC, the same with $10 \mathrm{mmol} / \mathrm{l}$ taurocholate. The number of experiments is given in parentheses. The results are given as mean \pm SEM.

Incubation or perfusion (min)

0

30

60

120

\begin{tabular}{lllr}
\hline Protein & & & $\mathrm{mg} \cdot 20 \mathrm{~cm}^{-1}$ \\
in vivo & Control (23) & - & $5.74 \pm 0.36$ \\
& $\mathrm{TC}(20)$ & - & $8.32 \pm 0.34$ \\
in vitro & Control (14) & $5.89 \pm 0.47$ & $10.76 \pm 0.55$ \\
& TC(13) & $6.13 \pm 0.39$ & $26.57 \pm 1.37$
\end{tabular}

$\mathrm{U} \cdot 20 \mathrm{~cm}^{-1}$

Alanine aminopeptidase (EC 3.4.11.2)

in vivo Control (24)

TC (25) TC (12) in vitro Control (13)

$0.042 \pm 0.002$

$0.053 \pm 0.003$

$0.131 \pm 0.013$

$0.542 \pm 0.033$

$\mathrm{U} \cdot 20 \mathrm{~cm}^{-1}$

$0.086 \pm 0.005$

$0.127 \pm 0.006$

$0.300 \pm 0.020$

$1.422 \pm 0.082$

$\mathrm{U} \cdot 20 \mathrm{~cm}^{-1}$

$\gamma$-Glutamyl transferase (EC 2.3.2.2)

$0.145 \pm 0.011$

$0.142 \pm 0.015$ in vivo Control (22)

TC (23)

in vitro Control (10) TC (7)

$0.084 \pm 0.004$

$0.153 \pm 0.007$

$0.185 \pm 0.015$

$0.659 \pm 0.042$

$\mathrm{U} \cdot 20 \mathrm{~cm}^{-1}$

Enteropeptidase (EC 3.4.21.9)

in vivo Control (22) TC (24)*

in vitrc Control (9) TC (9)*
$6.4 \pm 0.1$

$20.4 \pm 1.5$

$1.5 \pm 1.0^{\circ}$

$89.3 \pm 11.3$

$7.83 \pm 0.44$
$12.56 \pm 0.38$
$14.93 \pm 0.60$
$34.06 \pm 1.51$

$11.14 \pm 0.61$

$17.95 \pm 0.57$

$18.53 \pm 0.78$

$41.42 \pm 1.64$
$0.155 \pm 0.005$

$0.677 \pm 0.020$

$0.242 \pm 0.021$

$1.120 \pm 0.075$

$0.134 \pm 0.005$

$0.530 \pm 0.014$

$0.479 \pm 0.032$

$2.100 \pm 0.162$

$0.165 \pm 0.005$

$0.719 \pm 0.024$

$0.249 \pm 0.017$

$0.925 \pm 0.049$
$0.241 \pm 0.006$

$1.439 \pm 0.032$

$0.667 \pm 0.045$

$2.911 \pm 0.194$

$0.367 \pm 0.010$

$1.827 \pm 0.046$

$0.313 \pm 0.015$

$1.191 \pm 0.059$

$\begin{aligned} 31.9 & \pm 3.1 \\ 141.6 & \pm 7.2^{*} \\ 3.3 & \pm 1.0 \\ 107.2 & \pm 10.8\end{aligned}$

$\begin{aligned} 67.2 & \pm 3.2 \\ 405.1 & \pm 14.3^{*} \\ 5 \quad 5.0 & \pm 1.1 \\ \therefore \quad 129.8 & \pm 14.0\end{aligned}$


Tab. 1. Continued

$$
\text { Incubation or perfusion (min) }
$$

0

$\alpha$-1,4-Glucosidase (EC 3.2.1.20)

$\begin{array}{llll}\text { in vivo } & \text { Control (18) } & - & 0.46 \pm 0.03 \\ & \text { TC (20) } & - & 0.78 \pm 0.05 \\ \text { in vitro } & \text { Control (10) } & 0.08 \pm 0.04 & 0.78 \pm 0.10 \\ & \text { TC (8) } & 0.06 \pm 0.03 & 2.29 \pm 0.23\end{array}$

$1.76 \pm 0.16$
Glycyl-glycine dipeptidase (EC 3.4.13.1, now 3.4.13.11)

$\begin{array}{ll}\text { in vivo } & \text { Control (24) } \\ & \mathrm{TC}(19) \\ \text { in vitro } & \text { Control (8) } \\ & \mathrm{TC}(7)\end{array}$
TC (7)

Prolidase (EC 3.4.13.9)

in vivo Control (12) TC (12)

in vitro Control (8) TC (7)

$\mathrm{U} \cdot 20 \mathrm{~cm}^{-1}$

$0.22 \pm 0.01$

$0.39 \pm 0.02$

$1.19 \pm 0.09$

$2.73 \pm 0.30$

$\mathrm{U} \cdot 20 \mathrm{~cm}^{-1}$

$0.06 \pm 0.01$

$0.23 \pm 0.03$

$4.37 \pm 0.32$

$\mathrm{U} \cdot 20 \mathrm{~cm}^{-1}$

Leucine aminopeptidase:(EC 3.4.11.1)

in vivo Control $(20$

$\mathrm{TC}(26)$

in vitro Control (-11) TC (10)

$0.025 \pm 0.002$

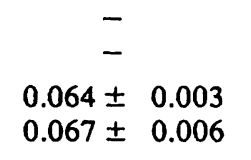

$0.081 \pm 0.003$

$0.187 \pm 0.016$

$0.521 \pm 0,060$

$\mathrm{U} \cdot 20 \mathrm{~cm}^{-1}$

Glycyl- $L$-leucine dipep
in vivo Control (16)
TC (17)

in vitro Control (7) TC (8)

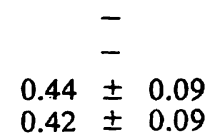

$0.36 \pm 0.03$

$6.90 \pm 0.43$

2.84. \pm 0.38

Prolinase (EC 3.4.13.8)

in vivo Control (15)

in vitro Control (7)

TC (7)

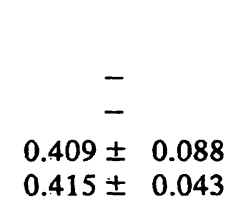

$\beta$-Glucuronidase (EC 3.2.1.31)

$\begin{array}{ll}\text { in vivo Control (10) } & \\ & \mathrm{TC}(10)\end{array}$

in vitrio Control (10)

TC (9)

Arylsulph hatase A (EC 3.1.6.1)

in vivo Control (10)
TC (10)

in vitro Control (10) TC (9)

$$
\begin{aligned}
& \mathrm{U} \cdot 20 \mathrm{~cm}^{-1} \\
& 0.045 \pm 0.009 \\
& 0.053 \pm 0.009 \\
& 1.809 \pm 0.173 \\
& 0.916 \pm 0.100 \\
& \mathrm{mU} \cdot 20 \mathrm{~cm}^{-1}
\end{aligned}
$$

$\begin{array}{ll}0.42 & \pm 0.20 \\ 0 & \\ 13.27 & \pm 1.47 \\ 60.33 & \pm 3.20\end{array}$

$\mathrm{mU} \cdot 20 \mathrm{~cm}^{-1}$

$\begin{array}{cc}- & 0 \\ - & 0 \\ 8.7 \pm 3.0 & 40.7 \quad \pm 3.7 \\ 9.6 \pm 3.2 & 102.9 \pm 10.0\end{array}$

$0.25 \pm 0.02$$$
\begin{aligned}
& 1.26 \pm 0.05 \\
& 2.90 \pm 0.10 \\
& 1.28 \pm 0.12 \\
& 3.35 \pm 0.36
\end{aligned}
$$

$3.02 \pm 0.06$

$7.09 \pm 0.18$

$1.84 \pm 0.19$

$4.40 \pm 0.47$

$0.44 \pm 0.02$

$1.37 \pm 0.05$

$1.79 \pm 0.17$

$3.80 \pm 0.37$

$1.19 \pm 0.05$

$3.87 \pm 0.16$

$2.38 \pm 0.18$

$4.73 \pm 0.42$

$0.11 \pm 0.01$

$1.30 \pm 0.06$

$2.48 \pm 0.16$

$5.83 \pm 0.46$

$0.36 \pm 0.03$

$4.06 \pm 0.15$

$3.62 \pm 0.28$

$7.36 \pm 0.63$

$0.044 \pm 0.002$

$0.519 \pm 0.017$

$0.293 \pm 0.026$

$0.851 \pm 0.107$

$0.103 \pm 0.004$

$1.311 \pm 0.029$

$0.397 \pm 0.035$

$1.051 \pm 0.134$

$0.60 \pm 0.03$

$1.45 \pm 0.07$

$11.29 \pm 0.75$

$4.38 \pm 0.32$

$1.78 \pm 0.10$

$4.55 \pm 0.16$

$15.05 \pm 0.71$

$5.92 \pm 0.37$

$0.099 \pm 0.013$

$0.167 \pm 0.012$

$2.549 \pm 0.220$

$1.181 \pm 0.107$

$0.260 \pm 0.023$

$0.496 \pm 0.024$

$3.358 \pm 0.240$

$1.786 \pm 0.175$

$0.87 \pm 0.48$

0

$25.5 \pm 2.13$

$216.26 \pm 17.20$

$2.12 \pm 0.88$

$0.64 \pm 0.34$

$39.73 \pm 2.13$

$311.86 \pm 23.07$ $\begin{array}{cc}0 & \\ 0 & \\ 64.7 & \pm 5.6 \\ 177.8 & \pm 17.7\end{array}$
0

$94.7 \pm 8.1$

$252.6 \pm 22.5$

* not corrected (see Material and Methods section).

in the case of $\alpha$-1,4-glucosidase and $\gamma$-glutamyl transferase.

By contrast, the cytosol enzymes are released considerably faster in vitro than in vivo. This is valid for glycylglycine dipeptidase, leucine aminopeptidase and prolidase. As for glycyl- $L$-leucine dipeptidase and prolinase, the release rates in vitro are much greater in the presence of Ringer solution alone than with Ringer and taurocholate in the medium.

The greatest differences are found for the lysosomal enzymes which were practically absent in the medium in vivo, but could be demonstrated in considerable quantities in vitro, especially under the additional effect of bile salt. 

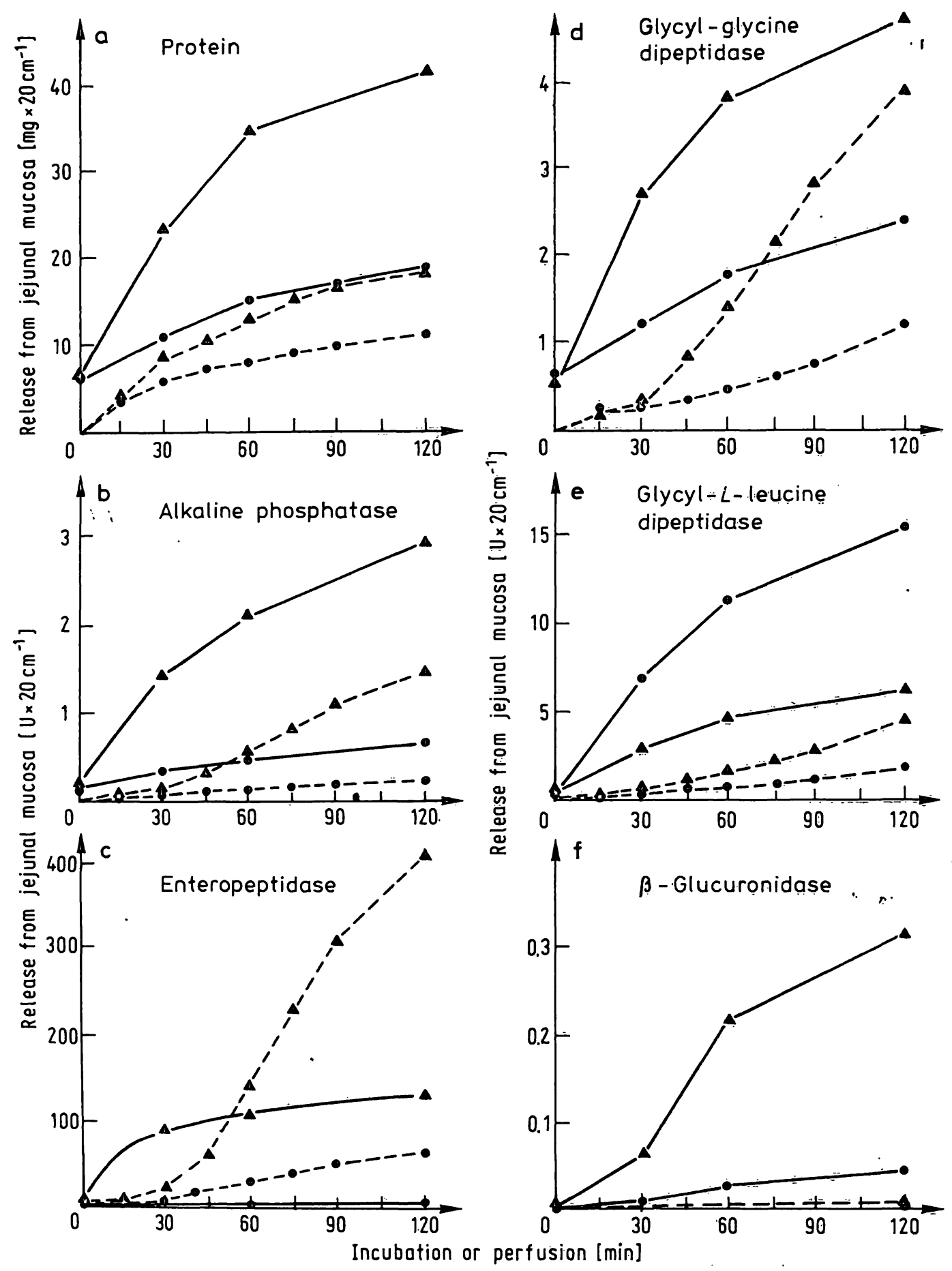

Fig. 1. Some typical examples illustrating the differences in release among enzymes of different location and stability.

$0--0$ in vivo, Ringer solution

$\Delta---\Delta$ in vivo, Ringer solution $+10 \mathrm{mmol} / \mathrm{l}$ taurocholate

0 in vitro, Ringer solution

$\Delta \longrightarrow$ in vitro, Ringer solution $+10 \mathrm{mmol} / \mathrm{l}$ taurocholate

For further explanation see Discussion. 


\section{Discussion}

Recently, it was demonstrated by Ugolev et al. $(2,3)$ that full transport capacity in the Wilson-Wiseman method is only achieved if additional serosal oxygenation is provided. In this case, for instance, the active assimilation of glucose is increased by $50 \%$. Therefore, the original in vitro method must be considered a hypoxia model, and hypoxia must be the main cause of the differences found between our in vivo and in vitro experiments.

It has long been accepted in clinical enzymology that deficient oxygen supply favours the release of cytosol enzymes from the cells (6). But it is interesting to note that in vitro glycyl-leucine dipeptidase (fig. 1e) and prolinase are liberated to a considerably greater extent in the absence than in the presence of bile salt. This is inversely correlated with the behaviour of the lysosomal enzymes. It might be supposed, therefore, that some cytosol enzymes are partially destroyed or inactivated by the action of lysosomal cathepsins (7) which, like $\beta$-glucuronidase (fig. 1f), are likely to be released to a much greater extent in the presence of bile salt.

Thus, enzymes such as glycyl-leucine dipeptidase and prolinase should have two characteristic properties, (1) they are susceptible to proteolytic attack and (2) they can easily leave the cell across the lipid bilayer of the plasma membrane. Both properties may be explained by a marked surface hydrophobicity of the enzyme molecules (see also 1,c. (8)).

In contrast to the cytosol enzymes, the removal of the plasma membrane enzymes appears to require energy. The type of anchoring of these enzymes in the membrane seems to be relevant. Enteropeptidase and $\alpha-1,4$-glucosidase, which are readily released, are embedded superficially in the membrane

\section{References}

1. Bossmann, B. \& Hajsctien, R. J. (1983) J. Clin. Chem. Clin. Biochem. 21, 1-9.

2. Ugolev, A. M. (1981) Adv. Physiol. Sci. 12, 9-24.

3. Ugolev, A. M. \& Eckert, L. G. (1982) Sechenov Physiol. J. USSR $68,150-162$.

4. Wilson, T. H. \& Wiseman, G. (1954) J. Physiol. 123, 116-125.

5. Suda, M. \& Ueda, K. (1963) in Newer Methods of Nutritional Biochemistry (Albanese, A. A. ed.). pp. 145-157. Academic Press, New York and London.

6. Friedel, R., Diederichs, F. \& Lindena, J. (1979) Adv. Clin. Enzymol. (Schmidt, E., Schmidt, F. W., Trautschold, I. \& Friedel, R., eds.) pp. 70-105, S. Karger, Basel etc.

7. Barrett, A. J. \& McDonald, K. J. (1980) Mammalian Proteases: a Glossary and Bibliography. Vol. 1: Endopeptidases. Academic Press, London. whereas alkaline phosphatase etc. are tightly anchored through a large transmembrane domain (9, $10,11)$. One might speculate that the usual shedding of plasma membrane enzymes is caused by "peristaltic" movements of the microvilli which are actively induced by way of the cytoskeleton. Another difference is constituted by the flow of the medium in the in vivo experiments. Its absence might be another cause of the rapidly declining release rates of enteropeptidase and $\alpha-1,4$-glucosidase in vitro.

The lysosomal membranes are damaged by intracellular acidosis (12). The appearance of lysosomal enzymes in the medium is clear evidence of serious cell damage (absent in the in vivo experiments). In general, the effects of hypoxia are enhanced by the presence of bile salt in the medium. It would be interesting to know if it aggravates the effects of hypoxia by penetrating the cells. Mitochondrial enzymes were not estimated in the present investigation.

The general tendency towards decrease of rates of enzyme release in the in vitro epxeriments may be explained by declining synthesis due to hypoxia. The problem of de novo synthesis of enzymes during increased release by bile acid is under investigation in our laboratory.

From a practical point of view enzymes are sensitive indices of cellular hypoxia. This is valid for

(1) lysosomal enzymes which under hypoxic conditions appear in the medium,

(2) cytosol enzymes some of which may be increased about tenfold in relation to fully oxygenated controls (prolidase, glycyl- $L$-leucine dipeptidase) in contrast to

(3) brush border enzymes, especially if located superficially in the plasma membrane (enteropeptidase, $\alpha-1,4$-glucosidase), whose shedding by the energy-deficient cells is impaired by hypoxia.

8. Bohley, P., Kirschke, H., Langner, J., Miehe, M., Riemann, S., Salama, Z., Schön, E., Wiederanders, B. \& Ansorge, S. (1979) in Biological Functions of Proteinases (Holzer, M., ed.), pp. 17-34, Springer Verlag Berlin-Heidelberg-New York.

9. Nordström, Ch. (1972) Biochim. Biophys. Acta 268, 711-718.

10. Moog, F. (1981) Scientific American 245, 116-125.

11. Colbeau, A. \& Maroux, S. (1978) Biochim. Biophys. Acta 51.1, 39-51.

12. De Duve, C. \& Gianetto, R. (1955) Biochem. J. 59, 433-445.

Prof. Dr. Reinhard Haschen Institut für Klinische Biochemie der Martin-Luther-Universität

Leninallee 2

DDR-4020 Halle 


i




\section{Viele Gründe sprechen für das System nach Maß:}

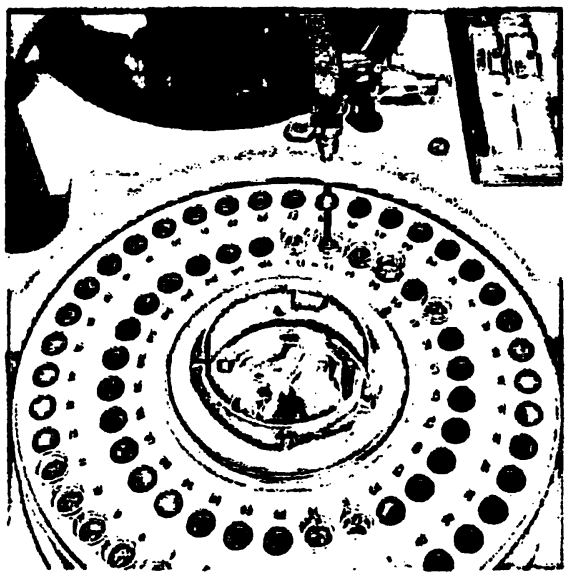

Routine, Eilanalysen mit Elektrolyten

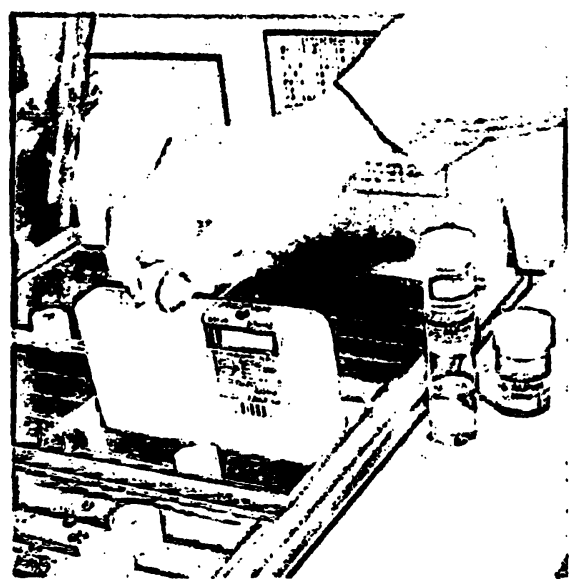

Maßgerechte

Packungsvarianten

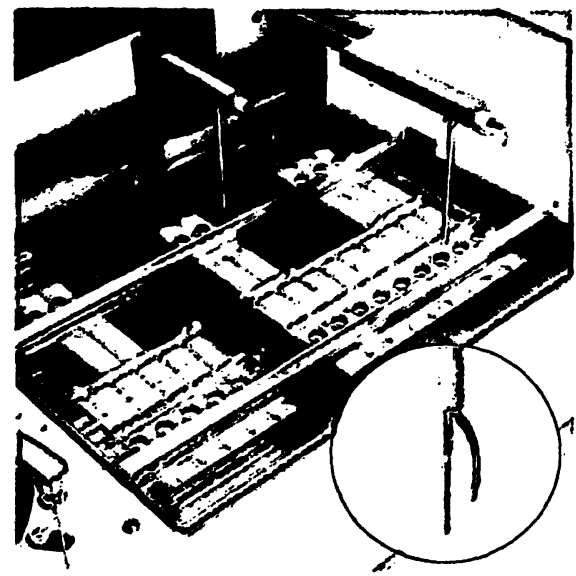

Sensorkontrolliertes Pipettiersystem

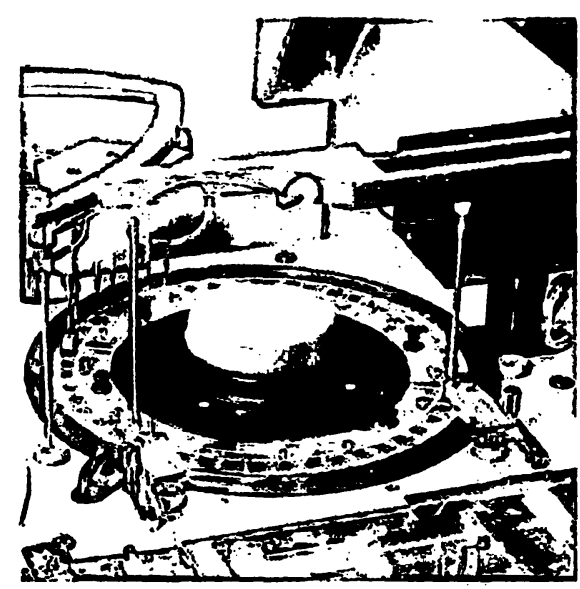

Reaktionsrotor

mit 48 Meßküvetten

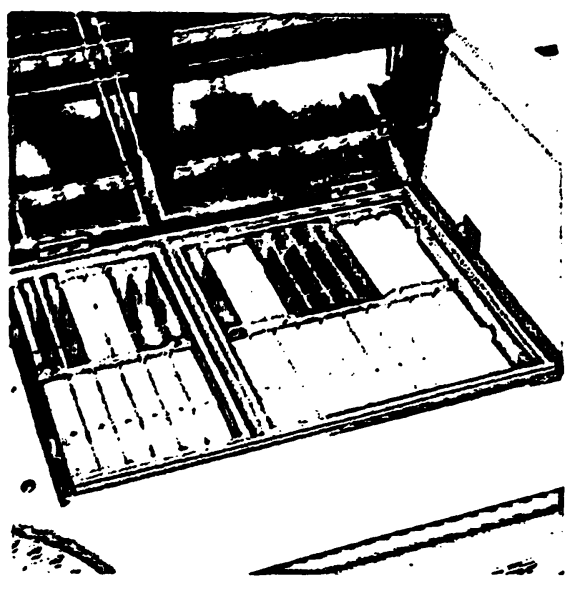

Integrierte Kühleinheit für Reàgenzien

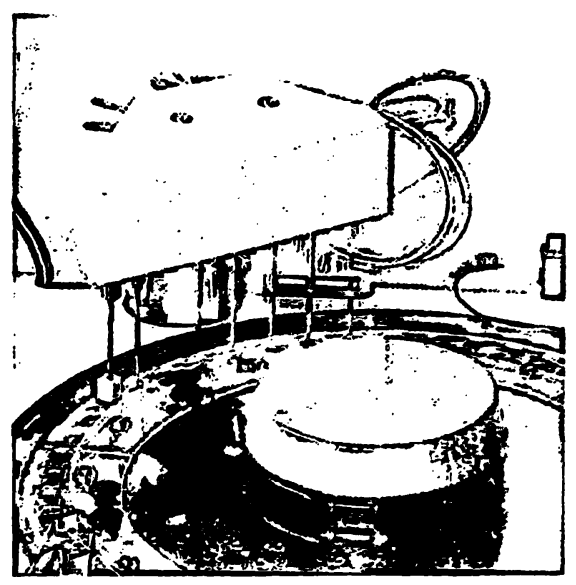

Wascheinheit mit integriertem automatischem Küvettenabglèich

HITACHI 705 die anspruchsvolle Gerätetechnik mit der hohen Wirtschaftlichkeit

Bitte um Aufnahme in

Ihren Hitachi-Infoservice

$$
\text { Straße }
$$




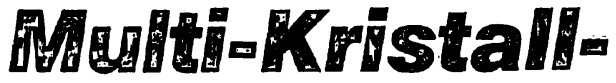

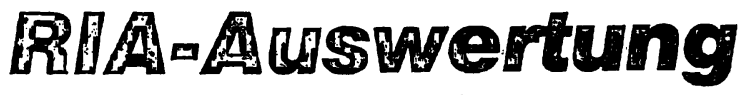 $\because \because$ 口 beỉ Rerthold:}

Unter anderem dieses:

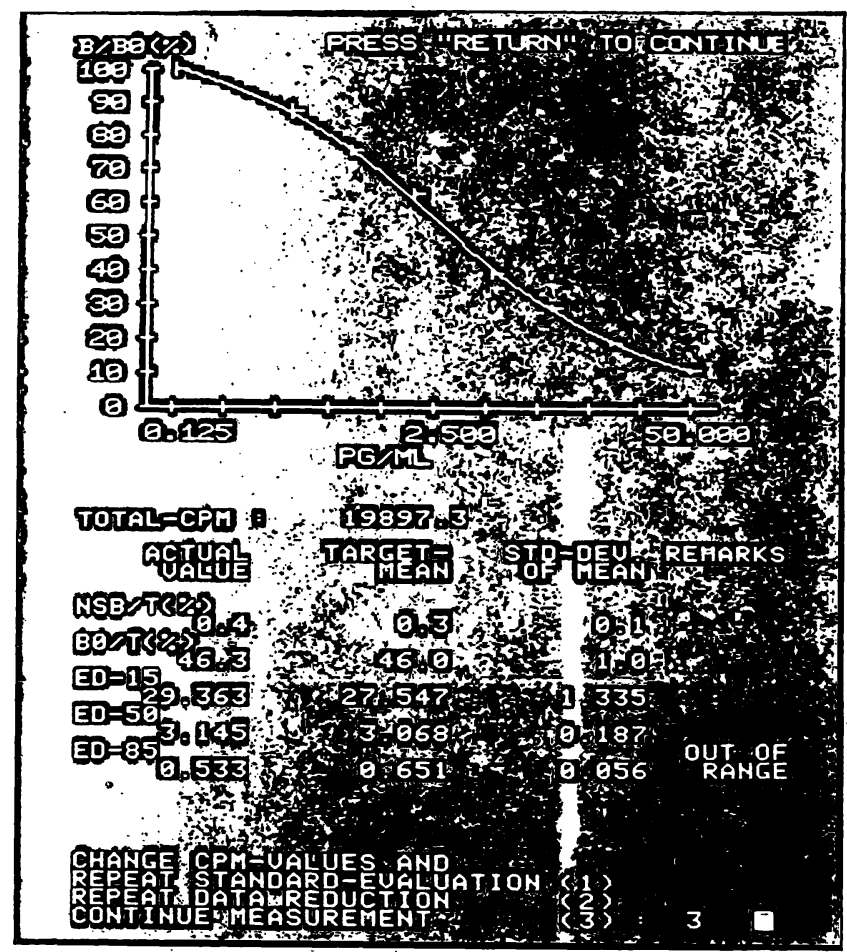

Unmittelbar nach Berechnung und Darstellung der RIA-Standardkurve wird der aktuelle Wert bestimmter Qualitätsparameter mit Ihrem statistisch abgesicherten Mittelwert verglichen und angezeigt, wenn'der Wert aus der Standardabweichung herausfällt.

Dies gibt dem.Arzt zusätzliche Sicherheit für die Auswertung der nachfolgenden Patientenproben.

Es ist jedoch nur ein Teilaspekt der gesamten, hochwertigen Qualitätskontrollen, die Ihnen unsere zwei neuen Multi-Kristall-Gammazähler bieten:

\section{LB 2102/500R mit freiprogrammierbarem Rechner LB 2103 mit eingebautem Rechner}

Sehen Sie selbst, was neu ist bei Berthold auf der

\section{MEDICA '83 in Düsseldorf}

vom 30. 11...bis 3. 12. 1983, Halle 4, Stand 4 E 08 Außer unseren Fachleuten und den neuen Geräten erwartet Sie dort auch ein Besucher-Quiz mit vielen schönen Preisen! 